\title{
The failure to obtain VC financing in the pre-start-up phase: Evidence from the Portuguese context
}

\author{
J. Bilau* \\ Polytechnic Institute of Beja / ESTIG, Beja, Portugal \\ Rua Pedro Soares, 7800-295 Beja, Portugal. \\ jose.bilau@ipbeja.pt \\ E. Couto \\ Technical University of Lisbon / ISEG, Lisbon, Portugal
}

Received July 2010

\begin{abstract}
In this paper, we contribute to the literature on access to venture capital during the pre-start-up phase of innovative firms by identifying the reasons for failing to obtaining formal $\mathrm{VC}$ according to nascent entrepreneurs. The main reasons cited for not obtaining venture financing were the small size of the VC market and limited public policies to support venture capital participation. The sub-sample of nascent entrepreneurs who based their financing proposals on more complete business plans included "lack of interest of the venture capitalists in pre start-up phase investments" as the number one reason.
\end{abstract}

*To whom all correspondence should be addressed.

\section{Introduction}

Access to Venture Capital (VC) financing is a crucial issue in the entrepreneurial finance literature. Previous research on access to formal VC financing approached the topic from the supply perspective, identifying, above all, the investment criteria of Venture Capital firms (VCs) when the firm to be funded is in more advanced phases and when the VC is more developed. Several authors have highlighted the scarcity of studies on VC that adopt a demand perspective (Mason \& Harrison, 1999; Brush, Carter, Greene, Hart \& Gatewood, 2002; Carter, Brush, Greene, Gatewood \& Hart, 2003; Amatucci \& Sohl, 2004).

Bozkaya \& Potterie (2008) carried out a study that included identifying the factors that technology-based small firm entrepreneurs cited to explain the difficulties in obtaining VC financing in the early stages of a firm. In this paper, we aim to deepen the knowledge on this topic with respect to the pre-start-up phase of innovative firms by identifying the reasons for the lack of success in obtaining formal $\mathrm{VC}$ mentioned by the nascent entrepreneurs. We do so by using a sample of Portuguese nascent entrepreneurs who were not successful when they tried to obtain VC financing during the pre-start-up phase of their innovative firms.

\section{The research questions}

Our goal is to contribute to the knowledge on VC financing by analysing the views of innovative nascent entrepreneurs on the wide-ranging set of factors, mentioned in the literature that caused them to fail to obtain $\mathrm{VC}$ financing during the pre-start-up phase of their firms.

In particular, the current study examines three central questions:

1. How do nascent entrepreneurs rank the importance of different factors when evaluating the reasons for their failure to obtain formal $\mathrm{VC}$ financing?

2. Does the nascent entrepreneur's degree of planning influence the evaluation of these factors?

3. Is there a difference in the evaluation of each of the factors by different subgroups of nascent entrepreneurs, where these subgroups resulted from applying a "quality of the business plan" criterion?

The remainder of our paper is structured as follows. In the next section, we briefly review the literature to contextualise the issue of access to VC financing. Section 3 presents a description of how the sample was compiled, the procedures used to obtain the data and the methods. The results of our analysis are presented in Section 4. They are discussed in Section 5, and the conclusions are outlined in Section 6.

\section{Literature}

Creating innovative companies and financing through venture capital

Innovation is recognised as an essential component of the economic growth process. An innovation is the 
implementation of a new or significantly improved product (good or service) or process or a new marketing or organisational method in business practices, workplace organisation or external relations (OECD, 2005). In Schumpeter's view, "radical" innovations create major disruptive changes, whereas "incremental" innovations continuously advance the process of change.

An innovative company can be defined as one that proposes to implement at least one type of innovation. The decision to innovate often takes place under great uncertainty (Rosenberg, 1994). Future developments in knowledge, technology, markets, product demand and potential uses for technologies can be highly unpredictable. The adoption of new products or processes or the implementation of new marketing or organisational methods is also fraught with uncertainty.

The characteristics associated with innovative firms, such as high risk and uncertainty, information asymmetries and an initial lack of tangible assets, raise additional financing problems for these firms (Sjogren \& Zackrisson, 2005; Hall $\&$ Lerner, 2010). These problems are especially delicate during the creation and initial phase of the firms and are more keenly felt in countries that have a culture that is geared towards bank financing.

VCs are financial intermediaries that raise funds from other investors, such as pension funds, banks, insurance companies, etc., to invest in young and innovative companies with high growth potential. VCs alleviate uncertainty and informal asymmetries associated with new and young firms by actively scrutinising firms intensely before providing capital and monitoring them afterwards (Gompers \& Lerner, 2001). VCs participate fully in the opportunities and risks and, in contrast to the banks, do not consider the issue of collateral and instead undertake an indepth analysis of the projects. Prior studies report a direct link between VC and innovation.

A study carried out on the European market by Bottazi and Da Rin (2002) showed that VCs support innovative European firms by providing them with the necessary funding for their creation and their development. Gompers and Lerner (2001) confirmed that the companies with VC funding patent more than those that had no $\mathrm{VC}$ funding. In addition, these companies also tended to have more patents related to radical innovations than other companies. Many new companies backed by VC are based on research results and prototypes developed in university laboratories (Lerner, 2002).

Historically, the sectors in which venture capital was involved were very dynamic in terms of innovation. They concentrated on computers and biotechnology in the 1980s and communications and the internet in the 1990s. Areas of concentration in the 2000s included nanotechnology, biomedical devices, genomics, and communications infrastructures.

\section{VCs' expectations of rates of return and a quick exit strategy}

VCs require higher than expected rates of return for earlystage investments due to the greater risk exposure (Pintado, Lema \& Van Auken, 2007). Mason and Harrison (1999), Murray and Lott (1995) and Dorf and Byers (2005) mentioned rates of return in the 40 to 70 per cent range for evaluating investments in the initial phases (seed and startup stages). The expectations of VCs with respect to the rates of return was cited by Belgian entrepreneurs of technologybased small firms as the second greatest cause for the difficulties in obtaining VC financing in the early-stage (Bozkaya \& Potterie, 2008). The high return rates required when assessing a potential investment may also explain the rejection of most VC financing requests by firms in the prestart-up phase.

VCs do not intend to remain as long-term investors in the firms that they help finance (Florida \& Martin, 1990). Large investors are more willing to supply funds to venture capital firms if they feel that they can later recoup their investment (Jeng \& Wells, 2000). Therefore, a viable exit mechanism is extremely important for the VCs. In the opinion of the entrepreneurs of technology-based small firms, the expectation of the VCs of a quick exit was the main reason behind the difficulties in obtaining VC financing in the early stages of their firms (Bozkaya \& Potterie, 2008). In 2005 in Europe, the main disinvestment method used was the trade sale (25 per cent), while there was also a modest number of IPOs (EVCA, 2006). In Portugal, the trade sale was also the most common, with no IPOs that year. It is likely that, in a country like Portugal with an underdeveloped IPO market, the exit mechanism will be cited as a factor that retracts the investments of the VCs.

\section{Stage of development / amounts of capital and venture capital investments}

Although Kaplan and Stromberg (1999, 2001) stated that more than a third of VC investments in the USA occur when the firms have not yet obtained profits, several studies have concluded that VCs are somewhat reluctant to finance earlystage firms (Pellón 1999; Hulsink, Van der Meer \& Meeusen-Henniger, 1999; Jud \& Kremshofer, 2000) and prefer firms in a more advanced phase (Timmons \& Sapienza, 1992; Timmons \& Bygrave, 1997). The financing of firms in the initial phase directly affects the VCs' investment analysis, especially with respect to assessing the risk and potential return (Carter \& Van Auken, 1994; Pintado et al., 2007).

The statistical data on Europe (EVCA, 2006) supports this analysis and shows that the number of VC investments of firms in the expansion phase is substantially greater than for firms in the seed and start-up stages. While in 2005, in Europe, the seed and start-up phases represented 26.5 per cent of the investments made by the VCs, in Portugal, the percentage was approximately half this figure (13 per cent), which leads us to surmise that the relative lack of interest of VCs in investing in firms in an initial phase may be one of the reasons cited by the Portuguese nascent entrepreneurs for the rejection of their proposals by the VCs. 
The size of the investment may also hinder the procurement of VC financing. Small investments are ignored by some venture capitalists (Timmons \& Sapienza, 1992). The preferred targets of VCs are businesses that need a relatively high investment sum. Dorf and Byers (2005) stated that, in the USA, only investments of more than 1 million USD are of interest to the VCs. The fixed costs of the due diligence that is carried out to protect the interests of the VCs and their shareholders prevent low value investments. In Europe, Bozkaya \& Potterie (2008) surveyed Belgian entrepreneurs of technology-based small firms who had difficulty in obtaining VC financing in the early-stage of their firms and concluded that one of the factors highlighted by the entrepreneurs for their failure was the lack of interest among the VCs to provide small amounts of capital.

\section{Technological support and business planning}

The entrepreneurial initiatives can also be differentiated according to the technology they use, which can stimulate the interest of the investors. According to Shane and Stuart (2002), the exclusivity licences or patents can be important factors for the success of a firm, and Teece (1986) even states that, in some situations, they are the major resource of a firm in the start-up phase. The literature supports a positive relationship between the existence of patents and the future increase in the value of the firms (Hall, Jaffe \& Trajtenberg, 2005) which makes them attractive for VCs. Venture capital operators gives precedence to investment in firms that possess exclusive singular and valuable new technology (Poser, 2003). As a consequence, it is possible that the lack of patents may hinder access to investment supplied by the VCs.

The business plan enables the nascent entrepreneurs to translate their idea into a business. Before all else, the business plan is the calling card that the entrepreneur uses to present the idea of the business to all of the entities related to entrepreneur. It is an important aspect when analysing the technical, economic and financial viability of the initiative. Through the financial forecasts included in the business plan, the entrepreneur can estimate the amount funding needed and the dates by which it has to be obtained.

Berger and Udell (1998) and Delmar and Shane (2003) referred to the importance of the business plan to obtain external finance. The business plan is also essential to attract VC financing, and its preparation is a crucial task in the process to obtain VC financing. The information that it contains on the entrepreneurial initiative and the entrepreneur and team make it a basic tool for the VCs to determine their financial participation (MacMillan, Siegel \& Narasimha, 1985; MacMillan \& Narasimha, 1987; Rhea, 1989; Tyebjee \& Bruno, 1986). Pintado and Lema (2004) concluded that the business plan is analysed meticulously by the VCs, who demand that it be shown by the firm's entrepreneurs prior to the start of negotiations (due diligence).

The perception by the nascent entrepreneur that the business plan is especially important in the process to obtain VC financing can lead to the nascent entrepreneurs to cite the poor quality or defective presentation of the business plan as one of the reasons for rejection of capital by the VCs.

\section{Characteristics of the nascent entrepreneur}

The curriculum of the entrepreneur and the team members who will work with him is one of the selection criterions for investment that is most often mentioned in the VC literature (Franke, Gruber, Harhoff \& Henkel, 2008). The VCs especially value industry experience, start-up experience and management experience (Tyebjee \& Bruno, 1984; MacMillan et al., 1985; MacMillan \& Narasimha, 1987; Bruno \& Tyebjee, 1985; Gorman \& Sahlman, 1989; Fried, Hisrich \& Polonchek, 1993; Rah, Jung \& Lee, 1994; Fried \& Hisrich, 1994; Zacharakis \& Myer, 1995; Muzyka, Birley \& Lelux, 1996; Wright, Robbie \& Ennew, 1997). This valuation may lead the nascent entrepreneurs to conclude that one of the reasons for investment refusal by the VCs is linked to the assessment of the capacities of both themselves and their team.

Studies on VCs place an emphasis on the role of active investors through monitoring (Kaplan \& Stromberg, 2001), which consumes a lot of time and significantly reduces the entrepreneur decision-making and control (Denis, 2004). Poutziouris, Chittenden \& Michaelas (1998), and a study carried out in the UK concluded that, in small firms, there is a natural control aversion. Although later studies found less aversion by the NTBF owner-managers when compared to the proprietors of small firms (Berggren, Oloffson \& Silver, 2000; Hogan \& Hutson, 2005), it is possible that the strong feeling of possession that is present in the creation phase of the firm may lead the nascent entrepreneur to raise objections to yielding part of the control to the VCs. Control aversion can be viewed by the nascent entrepreneurs as one of the reasons for refusing $\mathrm{VC}$ investment.

\section{Knowledge and capacities of the venture capitalists}

The VCs generally include staff in their workforce with high qualifications (for example, MBAs) who may understand the different kinds of business but who may find it difficult to understand the technology that is presented to them. This is especially true when having to deal with more innovative projects, given that true innovation involves complex technology (some of which may be ground-breaking). Small-scale VCs specialise in different industries or segments of industries that they know well, and they do not always have the capacity to assess projects based on truly ground-breaking technology. This lack of technological understanding and of specific knowledge and skills of the venture capitalists may also be seen by the nascent entrepreneurs as a factor that contributes to the rejection of the investment by the VCs.

\section{Public policies giving incentives to venture capital financing}

The development of innovative firms, which are important actors in the innovation system, is a necessary prerequisite of a healthy economy. These firms are the initial driving forces that bring about the advancement of technology and the dissemination of the innovations and new technology to traditional sectors. It is consensual that the return on 
innovation surpasses the private gain for society. Certain problems rooted in "market failures", such as the poor provisioning of finances, seem to impair the functioning of the innovation system in Europe (EC, 2002).

Acknowledgement of the significant return for society in tandem with some dysfunctions call for policies in order to make sure the innovation system gives its best contribution to the economic and social development. Hence, different policies, including those that encourage VC financing, are needed to facilitate and stimulate the development of innovative firms. In the case of $\mathrm{VC}$, there is a wide array of public policies. Clarification of the legal framework regulating the activity, attribution of tax benefits and direct government funding are perhaps some of the most wellknown government schemes (Jeng \& Wells, 2000). Whether or not these government schemes are in place can be a factor that pushes forward or inhibits the investment of the VCs. The nascent entrepreneurs may also link their failure to obtain VC to poorly implemented or a simple lack of government schemes such as these.

\section{Specificities of the venture capital market in Portugal}

Although the activity is growing, the venture capital market in Portugal is still of a small scale. According to the Portuguese Association of Venture Capital and Development (APCRI, 2007), at the end of 2005, the funds under management totalled $€ 1158 \mathrm{M}$, and the portfolio cost totalled $€ 669 \mathrm{~K}$. That year, the investment sum reached $€ 245 \mathrm{M}$ and encompassed 135 firms, while disinvestment in 90 firms reached $€ 176 \mathrm{M}$. The seed phase (13 investments) and start-up phase (53 investments) accounted respectively for 2 per cent and 11 per cent of the total investment in 2005. This small size of the VC market in Portugal may be one of the factors that contribute to the failure of the Portuguese nascent entrepreneurs in obtaining VC financing.

In small economies, there is a real problem in identifying the venture capitalists, unlike in large economies (EC, 2002). In Portugal, the first regulation governing the practices of the venture capital industry dates back to 1991. However, the activity only received a boost after changes made to the legislation in 2002. Since then, the governmental agencies and associations have made a big effort to disseminate venture capital, but as it is a relatively recent option, there may still be a lack of information about venture capital activities in Portugal, and this can also make it difficult for the nascent entrepreneurs to identify the VCs.

\section{Methodology}

\section{Sample}

Our study used a sample of nascent entrepreneurs (a person who is trying to start a new business) and involved two phases. The first identified a set of nascent entrepreneurs who were currently attempting to create an innovative firm. These nascent entrepreneurs were then monitored for a period of time (26 months), and at the end of which, they answered a follow-up questionnaire to ascertain the results of their efforts to obtain venture capital in the pre-start-up phase. We defined the pre-start-up phase as the period from the business idea to the date of the first sale. The association between the start-up of the firm and the first sale has been consistently used in the literature (Gatewood, Shaver \& Gartner, 1995; Carter, Gartner \& Reynolds, 1996; Newbert, 2005), so we also used these criteria in this study to identify the end of the pre-start-up phase. The initial sample we used in this study consisted of 476 nascent entrepreneurs (individuals and teams) who entered three innovative business ideas contests that took place in Portugal in the $2^{\text {nd }}$ and $3^{\text {rd }}$ quarters of 2004 , organised by government entities under the aegis of the Ministry of the Economy. Of the 141 answers obtained, 61 were excluded because the nascent entrepreneur stated that he had not attempted to obtain venture capital, returned incomplete answers or there were doubts about the innovative nature of the firm, and 17 were excluded because the nascent entrepreneur stated that he had obtained venture capital; thus, the final sample was reduced to 63 nascent entrepreneurs who attempted and did not manage to obtain venture capital, which translates into 13.24 per cent of the initial sample.

\section{Questionnaire and methods}

Information about the characteristics of the nascent entrepreneur and the business initiative was obtained through the ientities organizing the idea contest or by asking the candidates via email.

These information/ questions included (1) "kind of innovation proposed" to ascertain that the firm was indeed innovative and "description of the planning carried out" to evaluate the quality of the business plan (strong/few).

In the follow-up questionnaire, the nascent entrepreneurs were asked to assess the relative importance of 13 criteria that were identified in previous research. The questionnaire was sent in paper form and made available via the Internet. This questionnaire was based on Bozkaya, Romain and Van Pottelsberghe (2003) previous model used to survey nonlisted Belgian technology-based firms in 2002/2003 and contained several variables that are supported by the literature: the expectation of VCs of a quick exit (Jeng \& Wells, 2000), the expectation of VCs of high rates of return (Dorf \& Byers, 2005), unwillingness of VCs to provide small amounts of capital (Timmons \& Sapienza, 1992), lack of VC interest in early-stage investments (Timmons \& Bygrave, 1997), limited public policies to support VC participation (Jeng \& Wells, 2000 ), lack of registered patents by the company (Poser, 2003), lack of entrepreneurial and managerial skills (Muzyka et al., 1996) and poor quality of business plan and presentation to raise VC funds (Delmar \& Shane, 2003). The 13 variables in the follow-up questionnaire were measured using a five-point Likert scale: 5 was " extremely important", 4 was "very important", 3 was " mildly important", 2 was " not very important" and 1 was " unimportant".

The questions included the following: (1) lack of VC interest in pre-start-up phase investments; (2) unwillingness of VCs to provide small amounts of capital; (3) lack of understanding of the specific technology presented by many VCs; (4) lack of registered patents; (5) poor or defective 
quality of the presentation of the business plan; (6) lack of entrepreneurial and managerial skills of the nascent entrepreneur and/or the management team; (7) concerns over a loss of control in the firm to be created; (8) VCs' expectations about rates of return; (9) VCs' expectations about the chances of a quick exit; (10) lack of information about the VC activities in Portugal; (11) lack of specific knowledge and skills of the VCs; (12) limited public policies to support VC participation; and (13) small size of the VC financing market in Portugal.

The data were initially summarised using univariate statistics. The sample was subsequently segmented according to the quality of the business plan (strong/few). The nonparametric Mann-Whitney U-Test was used to identify differences between the two categories relative to the "quality of the business plan" criterion.

\section{Results}

Table 1 shows the univariate statistics obtained both for the sample $(N=63)$ and the sub-samples that resulted from the application of the "quality of the business plan" criterion.
Regarding the type of innovation in the sample, this was formed by innovation in product or service $(79,4 \%)$, process innovation $(14,3 \%)$ and innovation in terms of trade $(6,3 \%)$. Table 1 also includes the results of the nonparametric MannWhitney U-test of differences between means, which was used to identify differences between the categories relative to the "quality of the business plan" criterion.

The scores obtained in the sample (column 1) suggest that the small size of the venture capital market is considered to be the major factor by the nascent entrepreneurs behind their failure to obtain VC financing in Portugal. The second factor was considered as the limited public policies to support VC participation. Other important factors were the lack of $\mathrm{VC}$ interest in pre-start-up phase investments and the unwillingness of VCs to provide small amounts of capital. The aspects linked to the characteristics of the nascent entrepreneur (entrepreneurial and managerial skills and control aversion) that were also assessed were considered as the factors that least contributed to the rejection of their proposals by the VCs.

Table 1: Factors behind the failure to obtain VC financing in the pre-start-up phase: Mean, standard deviation and a Mann-Whitney test of differences between means by categories

\begin{tabular}{|c|c|c|c|c|c|c|}
\hline \multirow[t]{3}{*}{ Variables } & \multicolumn{2}{|c|}{$\begin{array}{l}\text { All Nascent Entrepreneurs } \\
\text { (1) }\end{array}$} & \multicolumn{4}{|c|}{$\begin{array}{c}\text { Quality of Business Plan } \\
\text { (2) }\end{array}$} \\
\hline & \multirow[t]{2}{*}{ Mean } & \multirow[t]{2}{*}{ S.D. } & \multicolumn{2}{|c|}{ Strong } & \multicolumn{2}{|c|}{ Few } \\
\hline & & & Mean & S.D. & Mean & S.D. \\
\hline VAR1 & 3,6667 & 1,40276 & 3,9000 & 1,20961 & 3,5581 & 1,48488 \\
\hline VAR2 & 3,4127 & 1,43274 & 3,7000 & 1,38031 & 3,2791 & 1,45284 \\
\hline VAR3 & 3,3810 & 1,49654 & 3,5500 & 1,43178 & 3,3023 & 1,53584 \\
\hline VAR4 & 2,7778 & 1,51811 & $3,3000(*)$ & 1,65752 & $2,5349(*)$ & 1,40321 \\
\hline VAR5 & 2,8254 & 1,28941 & 2,7000 & 1,38031 & 2,8837 & 1,25754 \\
\hline VAR6 & 2,1746 & 1,05555 & 2,0500 & 0,99868 & 2,2326 & 1,08753 \\
\hline VAR7 & 2,1270 & 1,12869 & 1,9500 & 1,19097 & 2,2093 & 1,10320 \\
\hline VAR8 & 3,2063 & 1,28463 & 3,2000 & 1,15166 & 3,2093 & 1,35503 \\
\hline VAR9 & 3,2222 & 1,17012 & 3,5500 & 0,99868 & 3,0698 & 1,22271 \\
\hline VAR10 & 3,1746 & 1,30186 & 3,2500 & 1,11803 & 3,1395 & 1,39012 \\
\hline VAR11 & 3,3492 & 1,28463 & 3,3500 & 1,08942 & 3,3488 & 1,37812 \\
\hline VAR12 & 3,8889 & 1,19287 & $3,3000(* *)$ & 1,26074 & $4,1628(* *)$ & 1,06749 \\
\hline VAR13 & 3,9841 & 1,00791 & $3,6000(* *)$ & 1,09545 & $4,1628(* *)$ & 0,92402 \\
\hline $\begin{array}{ll}\text { Valid } & \mathrm{N} \\
\text { (listwise) } & \end{array}$ & 63 & & 20 & & 43 & \\
\hline
\end{tabular}

(*) Significant at the 10 per cent level $(* *)$ Significant at the 5 per cent level $(* * *)$ Significant at the 1 per cent level

VAR1: Lack of VC interest in pre-start-up phase investments

VAR2: Unwillingness of VCs to provide small amounts of capital

VAR3: Lack of understanding of the specific technology presented of many VCs

VAR4: Lack of registered patents

VAR5: Poor or defective quality of the presentation of the business plan

VAR6: Lack of entrepreneurial and managerial skills (n. entrepreneur/management team)

VAR7: Concerns over the loss of control in the firm to be created

VAR8: VCs' expectations about the rates of return

VAR9: VCs' expectations about the chance of a quick exit

VAR10: Lack of information about the VC activities in Portugal

VAR11: Lack of specific knowledge and skills of the VCs

VAR12: Limited public policies to support venture capital participation

VAR13: Small size of the VC financing market in Portugal. 
nascent entrepreneurs who put a big emphasis on the planning stated that their failure to attract VC funding was due to the lack of interest by the VCs in investing in companies in the pre-start-up phase and in small investments, in contrast, the nascent entrepreneurs who attached less importance to planning pointed to the lack of public policies that support venture capital participation and to the small size of the VC market in Portugal as the main justifications for their failure to obtain $\mathrm{VC}$ financing. We found statistically significant differences $(p \leq 0.05)$ in relation to these last two variables that are considered as especially relevant for those who backed up their proposals on incomplete or poorly prepared business plans. Also in the "lack of registered patents", the probability value (p) was less than or equal to 0.10 , and it is the nascent entrepreneurs who put a big emphasis on planning who most believed that the lack of patents significantly contributed to the rejection of their proposals.

\section{Discussion}

In this study, the nascent entrepreneurs who failed to obtain $\mathrm{VC}$ financing during the pre-start-up phase of the innovative firms assessed the contribution of different factors to explain this fact. The first set of factors that was assessed is related to the specificities of the Portuguese venture capital market (market size, information about the VC, opportunities for a quick exit and public policies). The results obtained with respect to this first set of factors show that there is a perception that the small size of the venture capital market and the limited public policies to support VC participation can make a crucial contribution to the VCs' decision. When we subdivide the sample according to the "quality of the business plan" criterion, it emerges that the subgroup that gave more emphasis to producing a complete business plan attaches less importance to these two factors than those who spent less time on business planning. This leads us to surmise that an adequate planning of the business would have made it easier for this subgroup to gain access to the VCs, attenuating the idea that the small size of the venture capital market and the improper public policies are to blame for failing to attract venture capital. Despite the fact that the VC industry is relatively recent in Portugal, the nascent entrepreneurs surveyed did not raise questions on the information available about this kind of financing. The VCs' expectation of a quick exit is viewed as an important factor by the nascent entrepreneurs who made up the subgroups of the sample that emphasized planning more.

A second set of factors that was assessed is related to the venture capitalists. The contribution for the failure of their expectations about the rate of return, their lack of interest in small investments in the pre-start-up phase, the understanding of the technology presented and their specific knowledge and skills were also assessed by the nascent entrepreneurs. The results obtained match those of previous research that points out the interest of VCs in investing in firms at a more advanced phase. In effect, there seems to be a conviction among the surveyed sample that the pre-startup phase of firms is not the preferred phase for VCs to channel their investment $\left(3^{\text {rd }}\right.$ most mentioned factor in the sample). This conviction is even stronger in the subgroup that puts an emphasis on producing high-quality business plans; in this subgroup it was mentioned as the major factor. This subgroup seemed to doubt the technological knowledge of the VCs who turned down their requests for financing while not doubting their own specific knowledge and skills. Surprisingly, the VCs' expectations about rates of return, one of the VCs' selection criteria most referred to in the literature, was not viewed as an important factor by the nascent entrepreneurs surveyed. The nascent entrepreneurs also believed that the VCs may take a dim view of proposals that request low venture capital amounts. To sum up, the results of this second set of factors seem to indicate that there is a belief, especially among the nascent entrepreneurs with high-quality business plans, that the VCs are not overly concerned about the forecast rates of returns but that they do not fully understand the technology, have minimum investment benchmark amounts and are afraid to invest in firms in a pre-start-up phase.

A third group of factors is related to the characteristics of the nascent entrepreneur or the management team (willingness to yield part of the control and entrepreneurial / managerial skills) and the business initiative (lack of registered patents and quality of the business plan). With respect to the characteristics of the nascent entrepreneurs, the results show that the surveyed nascent entrepreneurs do not believe that these characteristics were important factors behind the rejection of their proposals by the VCs. We surmise that the commonly mentioned control aversion of small business entrepreneurs, much talked about in the literature, is not especially noticeable among the nascent entrepreneurs behind innovative business ideas, confirming the results of previous studies by Berggren et al. (2000) and Hogan \& Hutson (2005).

The results referring to the characteristics of the business initiative showed that the lack of a patent is not considered by the sample as a decisive factor behind the failure to obtain VC financing, but it is one of the factors that results in differences in opinion in the subgroups established based on the "quality of the business plan" criterion, and the entrepreneurs that put more emphasis on the business plan attached more importance to this factor.

\section{Conclusions}

This paper attempted to investigate the reasons underlying failures in obtaining formal VC financing. We did so from the demand perspective by using a sample of nascent entrepreneurs that were not successful when, during the prestart-up phase of their innovative firms, they attempted to obtain VC financing. This approach has rarely been taken in previous research, which usually opted to consider from the supply perspective and focused on more advanced phases of the firm, which are recognised to be of more interest to the VCs. We also split up the initial sample according to the "quality of the business plan" criterion to enable a more refined analysis and identification of the factors that differentiate the two subgroups resulting from applying the "quality of the business plan" criterion.

The findings enable us to draw the conclusion that the Portuguese nascent entrepreneurs believe that the structural aspects of the Portuguese venture capital market should be attributed a significant share of the blame for their lack of 
success. The main reasons cited for not obtaining venture capital financing were: 1) small size of the VC market in Portugal; 2) limited public policies to support VC participation; 3) lack of interest of the VCs in pre-start-up phase investments; and 4) unwillingness of VC suppliers to provide small amounts of capital. The sub-sample showed that the nascent entrepreneurs that based their financing proposals on more complete business plans included at the top of their list "lack of interest of the VC suppliers in pre start-up phase investments". The factors that most differentiated the nascent entrepreneurs who emphasised a high-quality business plan from those who did not make the business plan a high priority were the importance given to the public policies to support VC participation and the influence of the small size of the venture capital market in Portugal, both of which were attributed importance by the second subgroup.

We believe that these results can contribute to understanding the role played by the different factors in the process to obtain VC financing during the pre-start-up phase of innovative firms. The conclusions of this paper serve as a wake-up call to the policy makers in Portugal to be more aggressive in making public policies that support venture capital. It also confirms that venture capital operators pay little attention to investing in firms in the pre-start-up phase and tend to ignore financing requests that ask for low amounts.

However, as with all research, there are several limitations. We now outline some of these limitations and possible avenues of future research. The results obtained refer specifically to a given context (Portugal). To ascertain whether our conclusions can be generalised to other contexts, further research is necessary in other countries to validate our results. The sample comprises nascent entrepreneurs identified from contests held for innovative business ideas. In future research, an effort can be made to identify a random sample of innovative nascent entrepreneurs. It would also be important for a future study to include in the sample as a subgroup nascent entrepreneurs who managed to obtain venture capital but who encountered difficulties. Would the assessment results with this new sample be identical? This study may also be complemented by evaluating the reasons for rejecting funding by the VCs involved (supply perspective). It can lead to confronting the perception of the nascent entrepreneurs with the actual reasons by the key decision makers in the allocation process of the VC. Another suggestion would be to evaluate possible changes in $\mathrm{VC}$ funding in Portugal in the period after that of the present study.

Our analysis focused only on formal VC financing. In future studies, this analysis can also look at informal VC or compare the different kinds of $\mathrm{VC}$. Issues related to gaining access to $\mathrm{VC}$, which have a huge and wide-ranging potential for research and for which it is not easy to obtain suitably large samples, can be explored through qualitative methods such as case studies. This alternative approach can be useful to assess the influence of other factors (for example, characteristics of the business) or to focus specifically on some of the stages of the process to obtain venture capital financing.

\section{References}

Amatucci, F. M. \& Sohl, E. J. 2004. 'Women entrepreneurs securing business angel financing: Tales from the field', Venture Capital, 6(2-3):181-196.

APCRI. 2007. 'Anuário da APCRI 2006/2007'. [online] URL:http://www.apcri.pt/node/. Accessed 5 January 2009.

Berger, A. \& Udell, G.F. 1998. 'The economics of small business finance: The roles of private equity and debt markets in the financial growth cycle', Journal of Banking and Finance, 22: 613-673.

Berggren, B., Oloffson, C. \& Silver, L. 2000. 'Control aversion and search for external financing in Swedish SMEs', Small Business Economics, 15(3):233-242.

Bottazzi, L., Da Rin, M. 2002. 'Venture capital in Europe and the financing of innovatives compagnies', Economic Policy, 17(33).

Bozkaya, A. \& Van Pottelsberghe De la Potterie, B. 2008. 'Who funds technology-based small firms? Evidence from Belgium', Economics of Innovation and New Technology, 1(1\&2): 97 - 122.

Bozkaya, A., Romain, A. \& Van Pottelsberghe De la Potterie, B. 2003. Surveying technology-based small firms: A perspective from Belgium. Working Papers CEB 04-020. RS, Université Libre de Bruxelles, Solvay Business School, Centre Emile Bernheim (CEB).

Bruno, A.V. \& Tyebjee, T.T. 1985 'The entrepreneur's search for capital,' Journal of Business Venturing, 1(1): 6174.

Brush, G., Carter, N.M., Greene, P. G., Hart, M. M. \& Gatewood, E. 2002. 'The role of social capital and gender in linking financial suppliers and entrepreneurial firms: Framework for future research', Venture Capital, 4(4): 305323.

Carter, N.M., Brush, C.G., Greene, P.G., Gatewood, E. \& Hart, M.M. 2003. 'Women entrepreneurs who break through to equity financing: The influence of human, social and financial capital', Venture Capital, 5(1):1-28.

Carter, N.M., Gartner, B. \& Reynolds, P. 1996. 'Exploring start-up event sequences', Journal of Business Venturing, 11(3): $156-166$.

Carter, R. \& Van Auken, H. 1994. 'Venture capital firms preferences for projects in particular stages of development', Journal of Small Business Management, 32(1):60-74.

Delmar, F. \& Shane, S. 2003. 'Does business planning facilitate the development of new ventures?' Strategic Management Journal, 24:1165-1185.

Denis, D. J. 2004. 'Entrepreneurial finance: An overview of the issues and evidence', Journal of Corporate Finance, 10:301-326. 
Dorf, R. C. \& Byers, T. H. 2005. Technology ventures: From idea to enterprise. New York: McGraw-Hill.

European Commission (EC). 2002. 'Observatory of European SMEs, ${ }^{o} 6$,' [online] URL:ec . europa .eu / enterprise / enterprise policy / analysis / doc / smes observatory_2003_report6_en.pdf. Accessed on 8 January 2009.

EVCA. 2006. 'EVCA Barometer June / 2006'. [online] URL:euproject.vces.com/uploads/media/tmpl_27_art_43_att_1000pdf Accessed on 12 January 2009.

Florida, R. \& Martin, K. 1990. The breakthrough illusion: Corporate America's failure to move from innovation to mass production. New York: BasicBooks.

Franke, N.; Gruber, M.D., Harhoff, M. \& Henkel, J. 2008. 'Venture capitalists' evaluations of start-up teams: Tradeoffs, knock-out criteria, and the impact of VC experience', Entrepreneurship Theory and Practice, 32(3):459-483.

Fried, V. H., Hisrich, R.D. \& Polonchek, A. 1993. 'Research note: Venture capitalists' investment criteria: A replication', Journal of Small Business Finance, 3:37-42.

Fried, V.H. \& Hisrich, R.D. 1994. 'Towards a model of venture capital investment decision making', Financial Management, 23(3):28-37.

Gatewood, E.J., Shaver, K.G. \& Gartner, W.B. 1995. A longitudinal study of cognitive factors influencing start-up behaviors and success at venture creation', Journal of Business Venturing, 10(5) 371-391.

Gompers, P. \& Lerner J. 2001. 'The venture capital revolution', Journal of Economic Perspectives, 15(2):145168 .

Gorman, M. \& Sahlman, W.A. 1989. 'What do venture capitalists do?' Journal of Business Venturing, 4(4):231248.

Hall, B. H. \& Lerner, J. 2010. 'Financing R\&D and innovation'. In Hall, B.H. \& Rosenberg, N. (eds.). Handbook of the economics of innovation. Amsterdam: Elsevier.

Hall, B., Jaffe, A. \& Trajtenberg, M. 2005. 'Market value and patent citations', RAND Journal of Economics, 36:1638.

Hogan, T. \& Hutson, E. 2005. 'What factors determine the use of venture capital? Evidence from the Irish software sector', Venture Capital, 7(3):259-283.

Hulsink, W., Van der Meer, B. \& Meeusen-Henniger, E. 1999. High tech entrepreneurship in the low countries? Rotterdam: Erasmus Universiteit.

Jeng, L.A. \& Wells, P.C. 2000. 'The determinants of VC funding: Evidence across countries', Journal of Corporate
Finance, 6(3):241-289.

Jud, A. \& Kremshofer. T. 2000. Der Österreichische Beteiligungsmarkt. Joanneum Research:Vienna.

Kaplan, S. \& Stromberg, P. 1999. Financial contracting meets the real world: An empirical analysis of venture capital contracts. Working paper. Chicago, IL.: University of Chicago,

Kaplan, S. \& Stromberg, P. 2001. 'Venture capitalists as principals: Contracting, screening and monitoring', American Economic Review, 91:426-430.

Lerner, J. 2002. 'Boom and bust in the venture capital industry and the impact on innovation', Economic Review, Federal Reserve Bank of Atlanta, $4^{\text {th }}$ Quarter. Atlanta: Federal Reserve Bank.

MacMillan, I.C. \& Narasimha, P.N.S. 1987. 'Characteristics distinguishing from unfunded business firms evaluated by venture capitalist', Strategic Management Journal, 8:579585 .

MacMillan, I.C., Siegel, R. \& Narasimha, P.N.S. 1985. 'Criteria used by venture capitalists to evaluate new venture proposals', Journal of Business Venturing, 1(1):119-128.

Mason, C.M. \& Harrison, R.T. 1999. Venture capital: Rationale, aims and scope.' Venture Capital, 1:1-46.

Murray, G.C. \& Lott, J. 1995. 'Have UK venture capitalists a bias against investment in new technology-based firms?' Research Policy, 24:283-299.

Muzyka, D., Birley, S. \& Lelux, B. 1996. 'Trade-offs in the investment decisions of European venture capitalists', Journal of Business Venturing, 1(4):273-287.

Newbert, S.L. 2005. 'New firm formation: A dynamic capability perspective', Journal Small Business Management, 43(1):55-77.

OECD. 2005. Oslo manual: Guidelines for collecting and interpreting innovation data. Paris: OECD.

Pellón, J.M. 1999. 'Financión de la Innovación con Capital Riesgo', Papeles de Economía Española, 81:196-210.

Pintado, T.R.; Lema, D.G.P. \& Van Auken, H.V. 2007. 'Venture capital in Spain by stage of development', Journal of Small Business Management, 45(1):68-88.

Pintado, T.R. \& Lema, D.G.P. 2004. 'El Plano de Negocio en la Toma de Decisiones del Capital Riesgo en España', Harvard Deusto (Finanzas \& Contabilidad), 58:60-66.

Poser, T. 2003. The impact of corporate venture capital: Potentials of competitive advantage for the investing company. Wiesbaden, Glaber Edition Wissenshaft, Deutscher Universitats-Verlag.

Poutziouris, P., Chittenden, F. \& Michaelas, N. 1998. The 
financial affairs of private companies. Liverpool: Tilney Fund Management.

Rah, J., Jung, K. \& Lee, J. 1994.'Validation of the venture evaluation model in Korea', Journal of Business Venturing, 9(6):509-524.

Rhea, R.H. 1989. 'Factors affecting success and failure of seed/start-up negotiations', Journal of Business Venturing, 4(2):149-158.

Rosenberg, N. 1994. Exploring the black box: Technology, economics and history. Cambridge: University of Cambridge Press.

Shane, S. \& Stuart, T. 2002. 'Organizational endowments and the performance of university start-ups', Management Science, 48(1):154-170.

Sjogren, H. \& Zackrisson, M. 2005. 'The search for competent capital: Financing of high technology small firms in Sweden and USA', Venture Capital, 7(1):75-97.

Teece, D.J. 1986. 'Profiting from technological innovation: Implications for integration, collaboration, licensing and public policy', Research Policy, 15:285-305.

Timmons , J.A. \& Sapienza, H.J. 1992. 'Venture capital: The decade ahead'. In Sexton, D.L. \& Kasarda, J.S. (eds.). The state of the art of entrepreneurship. Boston: PWS-Kent, pp.402-437.

Timmons, J.A. \& Bygrave, W.D. 1997. 'Venture capital: Reflections and projections' In Sexton, D.L. \& Smilor, R. (eds.). Entrepreneurship 2000. Chicago: Upstart Publishing Co, pp.29-46.

Tyebjee, T.T. \& Bruno, A.V. 1984. 'A model of venture capitalist investment activity', Management Science, 30:1051-1066.

Tyebjee, T.T. \& Bruno, A.V. 1986. 'Negotiating of venture capital financing', California Management Review, 29:4559.

Wright, M., Robbie, K. \& Ennew, C. 1997. 'Venture capitalists and serial entrepreneurs', Journal of Business Venturing, 12(3):227-249.

Zacharakis, A.L. \& Myer, G.D. 1995. 'The venture capital decision: Understanding process versus outcome.' In Bygrave, W. D., Bird, B. J., Birley, S., Churchill, N. C., Hay, M., Keeley, R. H. \& Wetzel, W.E. (eds.). Frontiers of entrepreneurship research. Wellesley, MA: Babson College, pp.465-478. 